Abstracta Iranicacta Iranica

Revue bibliographique pour le domaine irano-aryen

Volume 28 | 2007

Comptes rendus des publications de 2005

\title{
Sargodašt-e Tehrān. Tehrān, Entešārāt-e Donyā, 1383/2004, 763 p. [Téhéran de jadis]
}

\section{Bernard Hourcade}

\section{(2) OpenEdition}

1 Journals

\section{Édition électronique}

URL : http://journals.openedition.org/abstractairanica/18121

DOI : 10.4000/abstractairanica.18121

ISSN : 1961-960X

Éditeur :

CNRS (UMR 7528 Mondes iraniens et indiens), Éditions de l'IFRI

Édition imprimée

Date de publication : 15 mai 2007

ISSN : 0240-8910

Référence électronique

Bernard Hourcade, «Sargoḍašt-e Tehrān. Tehrān, Entešārāt-e Donyā, 1383/2004, 763 p. [Téhéran de jadis] », Abstracta Iranica [En ligne], Volume 28 | 2007, document 198, mis en ligne le 18 septembre 2007, consulté le 25 septembre 2020. URL : http://journals.openedition.org/abstractairanica/18121 ; DOI : https://doi.org/10.4000/abstractairanica.18121

Ce document a été généré automatiquement le 25 septembre 2020.

Tous droits réservés 


\title{
Sargodašt-e Tehrān. Tehrān, Entešārāt-e Donyā, 1383/2004, 763 p. [Téhéran de jadis]
}

\author{
Bernard Hourcade
}

Parmi les nombreux ouvrages sur l'histoire de Téhéran à l'époque qājār, celui-ci se distingue par sa clarté (index) et son souci de présenter non seulement les bâtiments mais aussi les activités, équipements, quartiers, activités économiques, les questions d'hygiène, l'eau, l'administration le développement de la ville. Bien organisé en petits chapitres et développements bien documentés, ce livre donne une multitude d'informations certes connues, mais ici bien présentées et précises sur la capitale iranienne entre les règnes de Nāṣer ed-dīn Šāh et la révolution constitutionnelle. La bibliographie, abondante et uniquement en persan, est malheureusement classée par titres et non par auteurs. Il est également dommage que l'iconographie ne soit pas à la hauteur du texte de cet excellent ouvrage.

\section{INDEX}

Thèmes : 4.2.1. Safavides et Qâjârs

\section{AUTEURS}

\section{BERNARD HOURCADE}

CNRS / Mondes iranien et indien - Paris 